\title{
COMPREHENSIVE EVALUATION OF AERATED SOAKING FOR PADDY PARBOILING IN AN ECO-FRIENDLY MANNER
}

\author{
Neshankine C and Kannan $\mathrm{N}^{*}$ \\ Department of Agricultural Engineering, Faculty of Agriculture, University of Jaffna, Sri Lanka.
}

Received: 18 October 2021: Accepted: 27 November 2021

\begin{abstract}
Aerated soaking of paddy is a simple novel technique to utilize water effectively. Therefore, automated water circulation was maintained in the aerated soaking systems using a motor and timer. The timer was set with 70 minutes on-time and 20 minutes off-time. Hence, aerated soaking systems with operating cycles of 70 minutes ontime and 20 minutes off-time were developed based on dissolved oxygen profile in soaking water. The quality parameters of soaking water and rice were analyzed and compared with the conventional soaking process. In addition, moisture absorption pattern was also studied in aerated soaking systems and compared with the conventional soaking system. Results revealed that the aerated soaking of paddy improved hydration rate and reduced soaking time with a considerable reduction in effluent quality in terms of BOD. The moisture contents of conventional soaking, submerged aerated soaking and exposed aerated soaking were $27.84 \pm 0.01 \%, 30.41 \pm 0.01 \%$ and $31.48 \pm 0.01 \%$ respectively after 24 hours of soaking. The BOD values of conventional soaking, submerged aerated soaking and exposed aerated soaking were $1575 \mathrm{mg} / \mathrm{l}, 600 \mathrm{mg} / \mathrm{l}$ and $472 \mathrm{mg} / \mathrm{l}$ respectively after the end of soaking. The higher DO resulted in the germination of paddy grain which in turn reduced the head rice yield. The values of $\mathrm{pH}$, total dissolved solids, total solids and electrical conductivity of conventional soaking were highly different compared to submerged and exposed aerated soaking systems. The values of head rice percentage (HR$79.15 \pm 1.15 \%)$ and broken rice percentage (BR-20.84 $\pm 1.15 \%)$ of conventional soaking were almost similar to submerged aerated soaking (HR-79.51 $\pm 1.62 \%$ and BR-20.49 $\pm 1.63 \%$ ), but remarkably different from exposed aerated soaking (HR-60.74 \pm 2.00\% and BR-39.25 $\pm 1.99 \%$ ). The use of a submerged aerated system yielded a positive outcome related to hydration rate, reduction in terms of BOD $(975 \mathrm{mg} / \mathrm{l})$ value with reasonable milling yield profile in terms of head rice percentage. Hence, the system of submerged aerated soaking can be considered as a viable initiative for an eco-friendly parboiling process.
\end{abstract}

Keywords: Aeration, Cold-water, Evaluation, Paddy parboiling, Submerged aerated soaking.

\section{INTRODUCTION}

Rice (Oryza sativa) is one of the world's three most important edible starchy cereal crops. It plays a vital role in meeting global food demands. Approximately, half of the world's population consumes rice as a primary source of nutrition and it contributes $20 \%$ of the calories (Kubo and Purevdorj 2004). Consumption of rice increases with population growth. A substantial increase in the population is expected in the $21^{\text {st }}$ century (Kubo and Purevdorj 2004). Moreover, rice is the staple food grain in Sri Lanka with an annual per capita intake of $108.6 \mathrm{~kg}$ (Kumari et al. 2014a). Rough rice is processed in two

Corresponding author: aenkanna@gmail.com forms, raw rice and parboiled rice. Parboiled rice is a hydrothermally treated rice to tune physiochemical properties for better consumption (Itoh et al. 1985). However, parboiled rice accounts for around 55\% of total rice consumption in Sri Lanka (Kumari et al. 2014a) and it contributes to nearly 50\% of the energy and $40 \%$ of the protein in the daily diet of people in Sri Lanka (Sartaj and Suraweera 2005).

The method of parboiling consists of three stages such as soaking, steaming and drying (Igathinathane et al. 2005; Kannan et al. 2012; Kumari et al. 2014b). The main aim of soaking is to facilitate quick gelatinization of 
the paddy grains and to reduce energy consumption during steaming. The grain moisture content should be increased to at least $30 \%$ (wb) to have the perfect steaming process of parboiling (Kannan 2015; Kumari et al. 2014a; Wimberly 1983). For different grains, there are three soaking methods in use; cold soaking, hot soaking and vacuum soaking (Kumari et al. 2014a). The rate of moisture absorption is largely determined by the moisture gradient, environmental conditions and grain properties (Thakur and Gupta 2006).

The most common practice is soaking paddy in stagnant cold water for $36-72$ hours at room temperature. Because of the long duration of the cold soaking method, the microorganisms consume all of the dissolved oxygen in the soaking water and fermentation of starch, resulting in anaerobic conditions (Kumari et al. 2014a). This results in an odor in both the soaking water and the soaked paddy. To avoid these issues, it is a common practice to change the soaking water at regular interval $10-12$ hours (Rathnayake et al. 2010). For the manufacturing of parboiled rice, the soaking process uses a large volume of water and it is around 1.3 times the weight of paddy (Kannan 2015; Wimberly 1983). The volume of wastewater generated from the parboiling site is 0.4 to $0.521 / \mathrm{kg}$ of paddy processed. Wastewater contains a high concentration of organic and inorganic substances causing significant polluting effects (Sayanthan and Thusyanthy, 2018). In Sri Lanka, small and semi-modern mills are with higher production costs and limited milling output, resulting in low profitability. As a result, such millers commonly release wastewater into the environment without any treatment (Kumari et al. 2014a). The continual discharge of effluent into the environment causes several environmental problems (Thushyanthy et al. 2016). Moreover, effluent should be treated to come into the permissible level before disposal. Discharging effluent indiscriminately into the environment can make soil pollution, water pollution and air pollution by releasing noxious gases (Senanayake et al. 2001).

Hence, there is a need to modify the commonly used soaking process to solve such environmental consequences. Therefore, a simple aerated soaking system is considered to be helpful to reduce the microbial population, increase the water usage efficiency, reduce the oxygen demand, reduce effluent quantity and strength in terms of Biological Oxygen Demand (BOD) and increase the milling yield (head rice percentage) in an eco-friendly manner. It further created a piece of new knowledge about Dissolved Oxygen (DO) dynamics in soaking water during the simple aeration cycle of the aerated soaking system. As there are limited research works carried out on aerated soaking of paddy, this novel strategy and its investigations are helpful to propose eco-friendly soaking systems for paddy parboiling. Hence, this study was set to investigate the effect of submerged and exposed aerated soaking systems on effluent quality, paddy hydration and milling yield with an intention of proposing an eco-friendly strategy for the paddy parboiling process.

\section{MATERIALS AND METHODS}

The experiment was conducted at the Department of Agricultural Engineering, Faculty of Agriculture, University of Jaffna, Kilinochchi.

Long paddy grain variety $\mathrm{Bg} 251$ was selected for this study. Newly harvested dried paddy (moisture content - 13.4\% wb) was obtained from Paddy Research Institute, Paranthan, Kilinochchi. Impurities and foreign materials were removed from the paddy sample before the experiment.

\section{Simple aerated soaking system and its design}

Three PVC pipes of $1.5 \mathrm{~m}$ height and $100 \mathrm{~mm}$ diameter were used as the testing soaking tanks to represent conventional soaking (CS), exposed aerated soaking (EAS) and submerged aerated soaking (SAS) as shown in Fig. 1. A water pressure pump (ARPICO $90 \mathrm{~W} 230 \mathrm{~V} / 50 \mathrm{~Hz}$ ) was used to circulate the water through the PVC column. A $25 \mathrm{~mm}$ PVC pipe was used to circulate the water in the aeration unit. The pump was fixed with the SAS column and EAS column. A showerhead with fine holes of a diameter less 
than $1 \mathrm{~mm}$ was used to sprinkle water. The showerhead was kept $0.35 \mathrm{~m}$ above the top of the paddy soaking PVC pipes of EAS and SAS systems. A similar PVC column was made for traditional cold water soaking. Furthermore, in the SAS column, paddy was always submerged in water.

However, in the EAS column, paddy grains were exposed to the environment when water was circulated. Moreover, an automated water circulation system was maintained in the SAS and EAS systems using the pump and timer. It was programmed with 70 minutes on-time and 20 minutes off-time based on the Dissolved Oxygen (DO) of soaking water. This cycle was started after 12 hours of soaking and continued until the $30 \%$ (wb) moisture content of the paddy. The moisture content was measured by the oven-dry method to check the moisture profile to regulate the soaking cycle.

The experiment was designed to study the effect of aerated soaking systems (SAS and
EAS) on effluent quality and paddy grain quality. They were then compared with CS. Each experiment was conducted two times (two replicates).

The collected water quality parameters and paddy grain parameters of cold soaking were compared graphically with SES and EAS. A correlation analysis was done for checking the relationship between total dissolved solids (TDS) and dissolved oxygen (DO) and $\mathrm{pH}$ and DO. After obtaining $30 \%$ (wb) moisture content, paddy grains from all three soaking methods were steamed and dried $(14 \%$ wb) properly for a better milling process. Milling yield analysis for head rice yield, broken rice yield, whitebelly percentage, heat-damaged grains and whiteness values of polished grains were analyzed at the end. In addition, a correlation analysis was done with six values to check the regression analysis between whitebelly and whiteness value and whitebelly and heat-damaged grains. This study involved the determination of physical characteristics of paddy before and after soaking, soaking

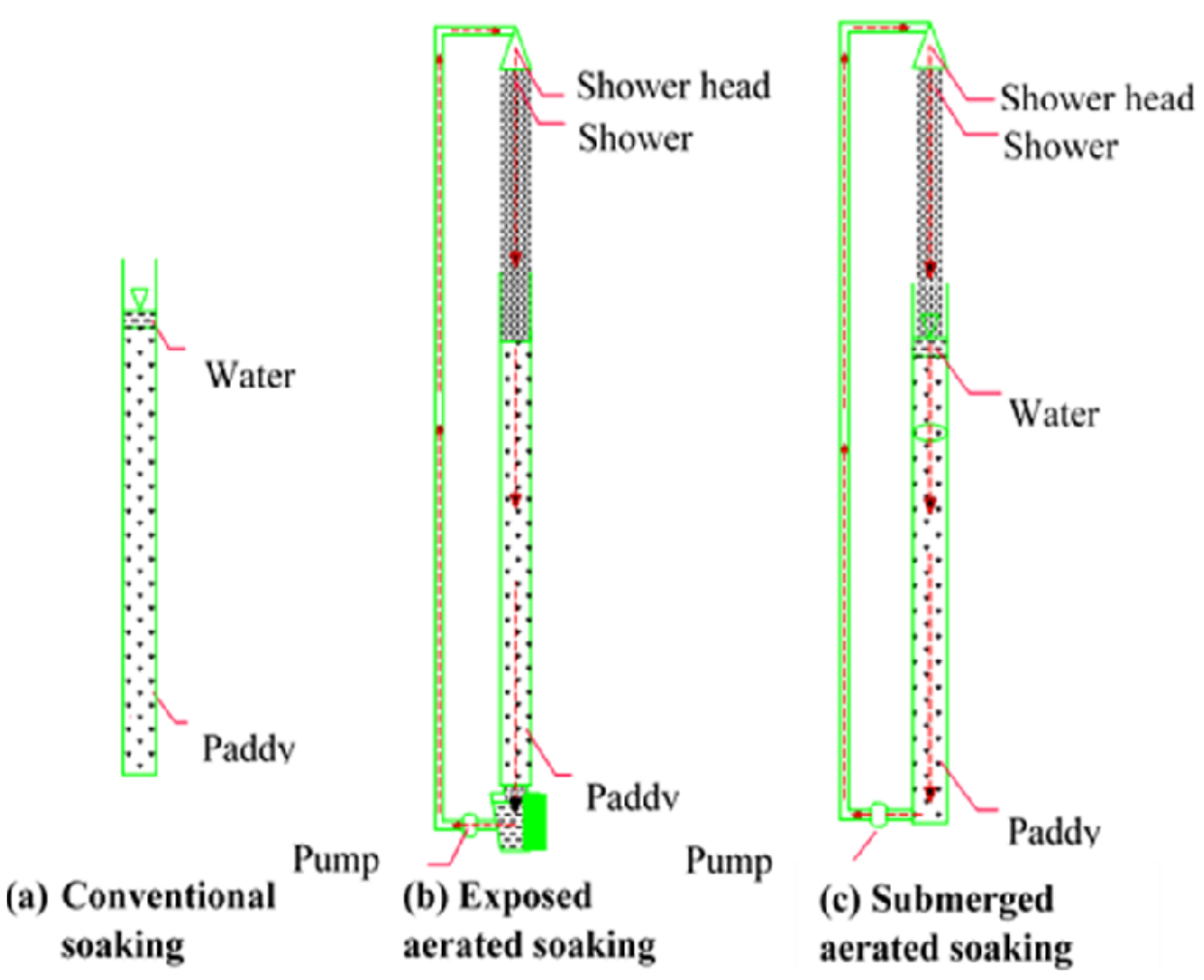

Figure 1: Drawings of CS (a); EAS (b); SAS (c) systems 
effluent characteristics and milling yield analysis. The instrumentation and measurement procedures are described below.

\section{Moisture content}

The standard oven-dry method was used to determine the moisture content of the paddy. Accurately measured $5 \mathrm{~g}$ of sample was kept in the oven overnight at $105{ }^{\circ} \mathrm{C}$. After drying, the final weight was measured (AOAC, 2000). Moisture content was calculated by the Eqn 1 (Kannan et al. 2012).

\section{Aspect ratio}

Length $(\mathrm{mm})$ and width $(\mathrm{mm})$ of randomly selected paddy samples were measured using vernier calliper with a reading error of 0.01 mm (Model: KANON E-PITA 20 Digital).
The aspect ratio was calculated by the Eqn 2 (Nadvornikova et al. 2018; Varnamkhasti et al. 2008).

\section{True density}

It was determined by the toluene displacement method (Ravi and Venkatachalam 2014). Since paddy absorbs toluene more slowly than water, toluene $\left(\mathrm{C}_{7} \mathrm{H}_{8}\right)$ was used instead of water. The preweighed paddy sample was placed into the known volume of toluene in a measuring cylinder. Toluene displacement was noted as volume $(\mathrm{ml})$.

\section{Bulk density}

It was determined using the mass/volume relationship (Ravi and Venkatachalam 2014). Therefore, paddy was filled into the empty container of predetermined volume and

$$
\begin{aligned}
& \% \text { Moisture content }(\mathrm{wb})=\frac{\text { Initial weight }(\mathrm{g}) \text {-Final weight }(\mathrm{g})}{\text { Initial weight }(\mathrm{g})} \times 100 \\
& \text { Aspect ratio }=\frac{\text { Width of paddy }(\mathrm{mm})}{\text { Length of paddy }(\mathrm{mm})} \\
& \text { Porosity }(\%)=1-\frac{\text { Bulk density }}{\text { True density }} \times 100 \\
& \text { Elongation percentage }=\frac{\text { Final length (mm)-Initial length }(\mathrm{mm})}{\text { Initial length }(\mathrm{mm})} \times 100
\end{aligned}
$$

Germination percentage $=\frac{\text { Number of seed germinated }}{\text { Total number of seeds taken }} \times 100$

Total Solids $(g / l)=\frac{\text { Final weight of beaker }(\mathrm{g}) \text {-Initial weight of beaker }(\mathrm{g})}{10 \mathrm{ml}} \times 1000 \mathrm{ml}$

Milling recovery $(\%)=\frac{\text { Weight of milled rice }(\mathrm{g})}{\text { Weight of paddy sample used }(\mathrm{g})} \times 100$

Head rice $(\%)=\frac{\text { Head rice weight }(\mathrm{g})}{\text { Sample weight }(\mathrm{g})} \times 100$

Broken rice $(\%)=\frac{\text { Broken rice weight }(\mathrm{g})}{\text { Sample weight }(\mathrm{g})} \times 100$

Heat damaged grains $(\%)=\frac{\text { Weight of heat damaged rice }(\mathrm{g})}{\text { Sample weight }(\mathrm{g})} \times 100$

Weightbelly (\%) $=\frac{\text { Weight of whitebelly }(\mathrm{g})}{\text { Sample weight }(\mathrm{g})} \times 100$ 
weight. Finally, a container containing the paddy sample was weighed and bulk density was determined.

\section{Porosity}

Bulk density $\left(\mathrm{g} / \mathrm{cm}^{3}\right)$ and true density $\left(\mathrm{g} / \mathrm{cm}^{3}\right)$ of randomly selected paddy samples were determined using standard methods. The values of the test characteristics were obtained and the porosity of the paddy sample was estimated using Eqn 3 (Ravi and Venkatachalam 2014; Varnamkhasti et al. 2008).

\section{Elongation percentage of paddy}

Paddy length was measured initially and it was continued until the end of soaking at 12 hours interval using a vernier calliper with a reading error of $0.01 \mathrm{~mm}$ (Model: KANON EPITA 20 Digital). Elongation percentage was calculated by the Eqn 4 .

\section{Germination percentage of paddy}

Paddy sample was mixed thoroughly and randomly selected 100 paddy grains were placed in the wetted tissue paper. Watch glass with soaked paddy was incubated at $27{ }^{\circ} \mathrm{C}$ in the dark (Kannan 2015). According to International Rice Research Institute (IRRI), the number of seeds germinated was counted at the end of the soaking from the first five days. Germination percentage was calculated by the Eqn 5 .

\section{Determination of parameters of soaking water}

Total solids content in the soaking water was determined by using an oven drying method (Thupeeban and Kannan 2017). A beaker with a capacity of $50 \mathrm{ml}$ was cleaned and placed into an oven for about three hours to remove all moisture. It was taken out and cooled in a desiccator at room temperature. The weight of the beaker was determined by standard analytical balance. A sample of 10 $\mathrm{ml}$ of the thoroughly mixed soaking water was placed into the beaker and the beaker was allowed to dry in the oven for three hours at $100{ }^{\circ} \mathrm{C}$. It was taken out and cooled in a desiccator at room temperature. The TS values were calculated using the Eqn 6 (APHA 1992).
TDS (mg/l) was measured using a multimeter (Model: HACH HQ 40d). A portable DO meter (Model: DO 31P) was used to measure the DO $(\mathrm{mg} / \mathrm{l})$ content of the soaking water and the meter was pre-calibrated in air and saturated water to make accurate DO measurements. The $\mathrm{pH}$ was measured by a multimeter (Model: HACH HQ 40d). It was calibrated by 4,7 and 10 standard $\mathrm{pH}$ solutions. The EC $(\mathrm{mS} / \mathrm{cm})$ of soaking water was measured by a multimeter (Model: HACH HQ 40d). All measurements (TS, TDS, DO, pH and EC) were taken at 2 hours intervals for soaking water of three different soaking methods until the paddy moisture content of $30 \%(\mathrm{wb})$. At the end of the soaking, BOD was measured by Winkler's titration method (APHA 1992).

\section{Steaming of paddy}

Steaming was done by an electric cooker (BR 910 ) and was completed as paddy grains were observed with split husk. It took 15-20 minutes to happen. Steaming was stopped as uniformly split husk had been observed (Hunt 2019).

\section{Drying of paddy}

Sun-drying was done. Paddy was spread on trays with $5 \mathrm{~mm}$ thickness. Paddy was turned up and down several times to make uniform drying. Paddy was dried to reach $12-14 \%$ moisture (wb) content to effective milling yield (Imoudu and Olufayo 1999).

\section{Milling yield analysis of parboiled paddy obtained from different treatments}

Milling yield analysis was done after dehusking and polishing. Analysis of milling yield in terms of head rice, broken rice, heatdamaged grains, whiteness value and whitebellies were determined using standard equations and methods used are given below.

\section{Milling recovery}

Milling was done in a small-scale rice mill located in Kilinochchi. After milling, bran and polished rice were weighed separately. The Eqn 7 was used to calculate the milling recovery percentage (Pokhrel et al. 2020). 


\section{Head rice percentage}

Head rice percentage was done using Length Grader (Model: Grainman length grader 68). Polished rice of $300 \mathrm{~g}$ was kept in the grader. The time $(50 \mathrm{Sec})$ and speed $(45 \mathrm{rpm})$ were set before running the grader. Analysis was done two times to increase the accuracy. The Eqn 8 was used to calculate the percentage of head rice (Thupeeban and Kannan 2017).

\section{Broken rice percentage}

Broken rice percentage was measured using Length Grader (Model: Grainman length grader 68). At that same time, head rice and broken rice were separated. The Eqn 9 was used to calculate the broken rice percentage (Thupeeban and Kannan 2017).

\section{Heat-damaged grains percentage}

Paddy sample of $100 \mathrm{~g}$ was measured and hand separation was done based on observation of grains. As at least $10 \%$ of its surface area has been burnt, it was identified as heat-damaged grains (Mamadou et al. 2011). The Eqn 10 was used to calculate the heat damaged percentage.

\section{Whitebelly percentage}

Rice contains an internal white region that is referred to as whitebelly (Xi et al., 2014). Paddy sample of $100 \mathrm{~g}$ was measured and hand separation was done. The Eqn 11 was used to calculate the whitebelly percentage (Thupeeban and Kannan 2017).

\section{Whiteness value}

The whiteness value of milled rice samples were measured by KETT Digital Whiteness Meter (Model: C-300-3). It was calibrated with ceramic to a value, 88.5. After that, paddy grains were placed. The displaced value was recorded as a whiteness value of samples placed.

\section{RESULTS AND DISCUSSIONS Physical properties of paddy}

The initial moisture content of paddy was recorded as $13.4 \%$ (wb). According to the International Rice Research Institute (IRRI), normally after harvesting, dried paddy contains a moisture content lesser than $14 \%$ (wb) (Imoudu and Olufayo, 1999). Furthermore, the length $(\mathrm{mm})$ and width $(\mathrm{mm})$ of paddy grains were $7.82 \pm 0.01$ and $2.64 \pm 0.06$ respectively. It belongs to long grain under size classification and medium grain under shape classification (Chemetova 2013). The aspect ratio was calculated as 0.33 . The porosity of paddy grain was calculated as $48.98 \pm 3.70 \%$. Furthermore, bulk density and true density of long paddy grain are $0.59 \pm 0.02 \mathrm{~g} / \mathrm{cm}^{3}$ and $1.16 \pm 0.08 \mathrm{~g} / \mathrm{cm}^{3}$ respectively. However, researchers reported porosity, bulk density and true density of paddy grains were to be $46-54 \%, 0.563$ $0.642 \mathrm{~g} / \mathrm{ml}$ and $1.182 \mathrm{~g} / \mathrm{ml}$ respectively (Bhattacharya et al. 1972). The information obtained in this section was highly useful to make a better scientific analysis of aerated soaking of paddy parboiling.

\section{Moisture content change}

Fig. 2 shows the relationship between the moisture content of paddy grains and soaking time of three different soaking methods. It is obvious from Fig. 2 that during the first 12 hours of soaking, a weighty rise in moisture content was observed in three different soaking methods due to the high moisture gradient that existed between paddy grain and soaking water environment (Kannan 2015; Thakur and Gupta 2006). However, moisture content changed very differently after 12 hours of soaking. Moreover, the rapid increase observed in the EAS and SAS compared to $\mathrm{CS}$ is due to the water circulation and aeration. Moisture content values for CS, SAS and EAS were $27.84 \pm 0.002 \%$, $30.41 \pm 0.007 \%$ and $31.48 \pm 0.01 \%$ respectively after 24 hours of soaking. Both the aerated soaking systems were stopped after 24 hours due to the moisture content of $30 \%$ (wb). However, it took 48 hours to reach $30 \%$ (wb) moisture content in CS. This delay is due to the slow migration of moisture into paddy grains (Kannan 2015; Kumari et al. 2014a). During 24 - 48 hours, the rate of increasing moisture content was lower than the first 24 hours due to the formation of solid boundary around the paddy grain as the stagnant water prevailed. Moreover, this layer prevents the penetration of the water molecules inside the paddy grain. The same observation was 


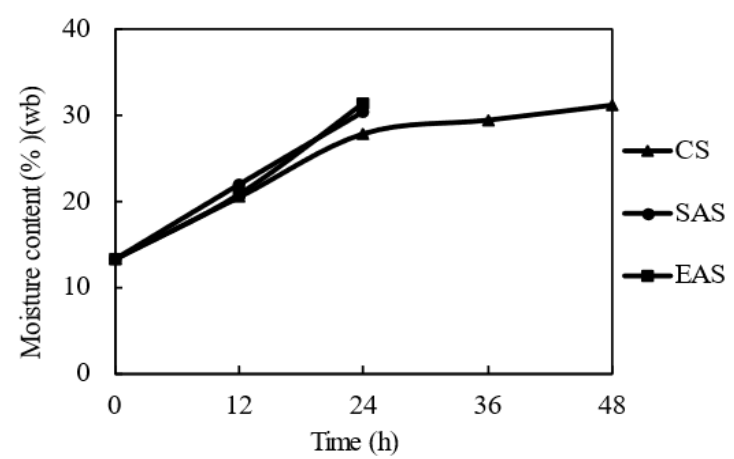

Figure 2: Effect of aeration on moisture absorption of paddy grains

reported already in aerated soaking of paddy (Kannan 2015; Kumari et al. 2014a).

\section{Elongation percentage}

Fig. 3 shows the elongation percentage of paddy during three different soaking methods. During the first 12 hours, elongation percentage increased linearly in all three different soakings due to a considerable big rise in the moisture content. The primary cause of the dimensional change was moisture gain during soaking. The starch granules found in endosperm swell after absorption of moisture, leading to dimensional transition (Kale et al. 2017). Another explanation is that when soaking paddy grains, cracks in the grain are filled and widened (Kale et al. 2017). However, the elongation percentage is very different after 12 hours of soaking. Moreover, a rapid increase in elongation was observed in SAS and EAS due to water circulation and rapid absorption of the moisture in paddy. Finally, $\mathrm{CS}, \mathrm{SAS}$ and EAS paddy reached elongation percentages of $10.24,10.36$ and 10.56 respectively. During 36 - 48 hours of soaking, elongation of paddy was $0.13 \%$ in the CS. This value is highly different compared to the first 24 hours of soaking due to the obstruction given by husk to grains for swelling (Kale et al. 2017). However, after the removal of husk, during cooking, remarkable elongation does usually happen (Kale et al. 2017).

\section{Germination percentage}

Fig. 4 shows the germination percentage of three different soaking methods after reaching

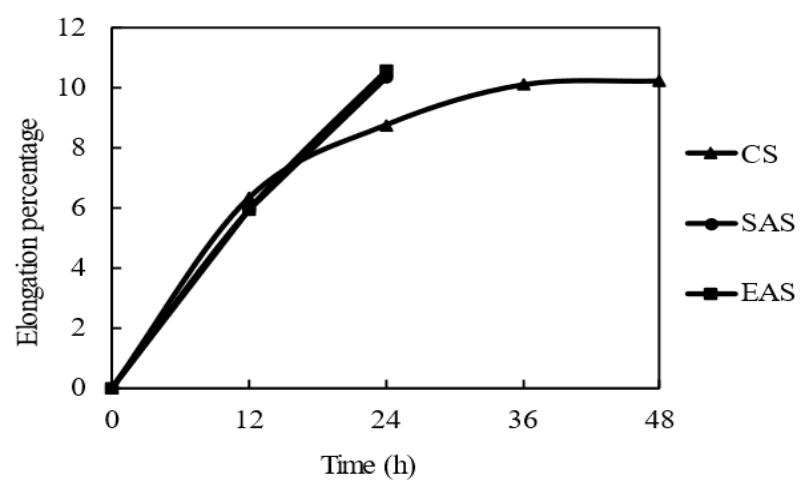

Figure 3: Effect of aeration on elongation of paddy grain

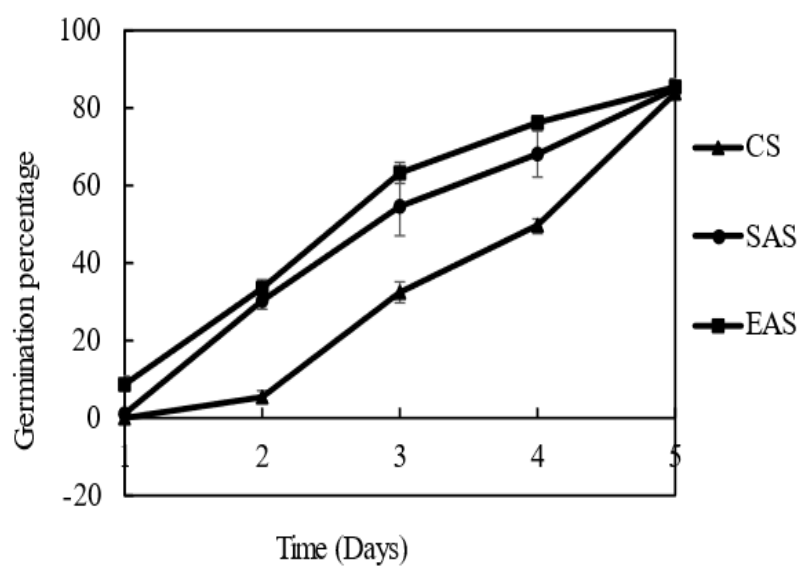

Figure 4: Germination of paddy after soaking

the moisture content of $30 \%$ (wb). The germination percentage reached $84.00 \pm 1.82 \%$, $85.00 \pm 2.44 \%$ and $85.25 \pm 2.21 \%$ for CS, SAS and EAS respectively after 5 days. After soaking, $8.75 \pm 1.70 \%$ of germination was observed during the first day for the EAS. It was greatly higher during the second day. Germination percentages were observed to be $6.00 \pm 1.29 \%, 30.00 \pm 2.16 \%$ and $33.50 \pm 1.91 \%$ for CS, SAS and EAS respectively during the second day. These differences are due to different DO concentrations in different soaking methods. Paddy grain germination is induced when a favourable environment is provided by soaking water (Kannan, 2015). The high availability of oxygen in soaking water induces germination of the paddy grains (Panchan and Naivikul 2009).

\section{Characterization of water}

Tap water which was taken from the Department of Agriculture Engineering, 
Faculty of Agriculture was used to soak the paddy grains. Before using water, TS, DO, $\mathrm{pH}$, TDS and EC values were determined. Initial values of $\mathrm{pH}, \mathrm{DO}, \mathrm{EC}$, TDS and TS of used water were $7.53 \pm 0.08,7.91 \pm 0.04 \mathrm{mg} / \mathrm{l}$, $2470 \pm 98.99 \mu \mathrm{S} / \mathrm{cm}, 1088.5 \pm 21.92 \mathrm{mg} / \mathrm{l}$ and $1.2 \pm 0.01 \mathrm{~g} / 1$ respectively. This piece of information is critical for analyzing changes in these parameters during different soaking methods.

\section{Dissolved Oxygen (DO)}

Fig. 5 shows the effect of aeration on DO of three different soaking methods. It is obvious from Fig. 5 that the DO value gradually decreased during the first 6 hours of three soaking methods due to the activation of aerobic microorganisms in the soaking water (Kannan, 2015). They utilized the DO in the water. After that, during 6 - 10 hours, a notable reduction of DO was observed in the soaking water. Researchers reported similar pattern as reported in this study because microbial activities are determinants of the $\mathrm{DO}$ and $\mathrm{pH}$ of soaking water based on the availability of the organic matter (Kannan 2015; Ramalingam and Raj 1996).

DO values for CS, SAS and EAS were $2.34 \pm 0.02 \mathrm{mg} / \mathrm{l}, \quad 1.85 \pm 0.03 \mathrm{mg} / \mathrm{l}$ and $1.95 \pm 0.04 \mathrm{mg} / \mathrm{l}$ respectively after 12 hours of soaking. However, DO changes are very different after 12 hours of soaking in SAS and EAS due to the aeration process. Both aerated soaking systems were stopped after 24 hours of soaking which yielded $30 \%(\mathrm{wb})$ moisture content required for effective soaking. Therefore, SAS and EAS systems are set with no DO values after 24 hours.

However, it continued for CS up to 48 hours of soaking cycle by which required moisture content of $30 \%$ (wb) was obtained and end of the soaking DO reduce to $0.89 \pm 0.01 \mathrm{mg} / \mathrm{l}$. It has been reported that soaking water of CS exhibited DO values of $0.9 \mathrm{mg} / 1$ (Pradhan and Sahu 2004; Sayanthan and Thusyanthy 2018). A notable rise was observed during 12 to 14 hours of EAS and SAS because after 12 hours of soaking water circulation started. It lead to a rapid DO increase due to atmospheric diffusion.
During 14 to 24 hours of soaking, DO value decreased due to the dynamics of the aerobic microorganisms. The DO values of SAS, EAS and CS were $2.19 \pm 0.02 \mathrm{mg} / 1,3.15 \pm 0.17 \mathrm{mg} / 1$ and $2.09 \pm 0.01 \mathrm{mg} / 1$ respectively after 24 hours of soaking. Both the SAS and EAS yielded higher DO than the CS system. However, the DO value of EAS is higher than the SAS system because of different mechanisms of oxygen addition. In the EAS system oxygen addition is through the atmosphere and paddy column. Hence, its values are always higher than other methods (Kannan 2015). Therefore, the observations made in this study are in line with reported findings.

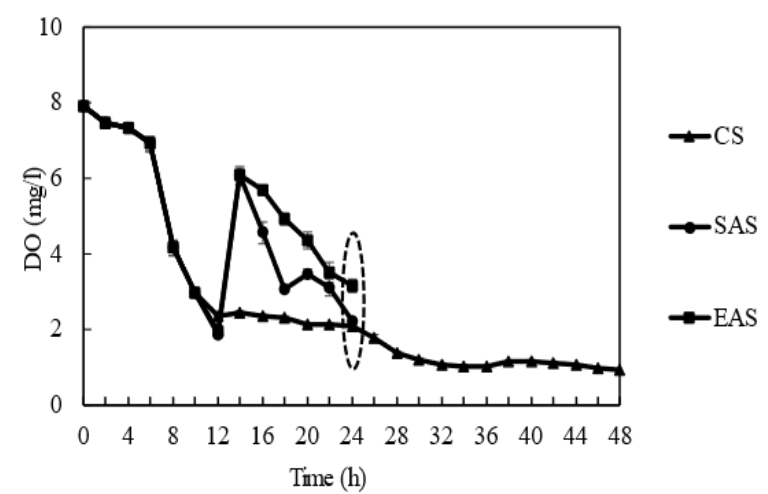

Figure 5: Effect of aeration on DO of three different soaking methods

\section{Biological Oxygen Demand (BOD)}

Fig. 6 shows the BOD value of three different soaking methods in $\mathrm{mg} / \mathrm{l}$. The values of BOD were $1575 \mathrm{mg} / 1,600 \mathrm{mg} / 1$ and $472 \mathrm{mg} / 1$ for $\mathrm{CS}, \mathrm{SAS}$ and EAS respectively. It has been reported that the BOD values of CS, SAS and EAS were $950 \mathrm{mg} / 1,750 \mathrm{mg} / 1$ and $700 \mathrm{mg} / \mathrm{l}$ respectively (Kannan 2015). The prominent difference in BOD values has been observed in both aerated soaking systems compared to the CS method. The value of BOD was lower in both SAS and EAS compared to CS due to the artificial aeration provided in aerated soaking systems. Moreover, in EAS and SAS processes, DO addition was made by aeration which resulted in lower BOD values. The reason for the high $\mathrm{BOD}$ value in $\mathrm{CS}$ is the hydrolysis of organic materials presented in paddy grains. 


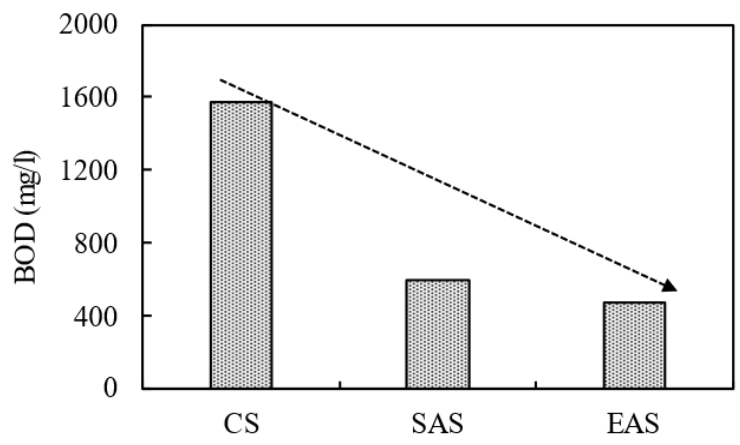

Figure 6: Effect of aeration on BOD value of three different soaking methods

These organic materials can be oxidized quickly in the aerated soaking system due to the addition of DO via aeration. Therefore, the demand for oxygen is less in SAS and EAS systems. The reduction of BOD value due to aeration has been reported in an aeration soaking environment (Kannan, 2015; Ouyang and Juan, 1995). Moreover, soaking durations of CS, SAS and EAS were 48 hours, 24 hours and 24 hours respectively. Furthermore, when the duration of soaking increased, it also induced the microbial population and their dynamics in both paddy and soaking water (Ramalingum and Raj 1996).

\section{Total Dissolved Solids (TDS)}

Fig. 7 shows the effect of aeration on TDS of three different soaking methods. It is obvious from Fig. 7 that the TDS concentration increased almost linearly during the first two hours of soaking for all three methods of soaking due to the higher concentration gradient of solid existed between grains and soaking water environment. This higher concentration gradient induced the movement of soluble solids into soaking water resulting in an increase of solid concentration in the soaking water. Moreover, during the period of soaking from 8 - 12 hours, TDS concentration again increased due to the degradation of soluble solids as a result of high microbial activity.

Moreover, the TDS value, $2800 \mathrm{mg} / 1$ for CS of paddy grains was obtained after the end of the soaking (Thushyanthy et al. 2016). However, TDS changes were very different after 12 hours of soaking in SAS and EAS systems compared to CS due to the influence of aeration on solids dynamics. The aerated soaking system was ceased after 24 hours of soaking as it reached a grain moisture content of $30 \%(\mathrm{wb})$ required for effective milling. Therefore, SAS and EAS were set have no value of TDS after 24 hours of soaking. However, the CS system took 48 hours to reach the grain moisture content of $30 \%(\mathrm{wb})$ required for effective milling. Therefore, it was able to get $1897.0 \pm 11.31 \mathrm{mg} / \mathrm{l}$ value for TDS after 48 hours of soaking. The highest TDS value observed for the SAS method was due to high suction force developed during aeration under the submerged condition of grains.

This highest suction force in SAS resulted in higher leaching rates. Furthermore, the degree of suction force is low for EAS compared to the SAS system. Therefore, the TDS concentration of the SAS system is high compared to the EAS system. The increasing trend in TDS concentration was observed for all three soaking systems due to the degradation of solids into soaking water by developed microbial colonies.

\section{Electrical Conductivity (EC)}

Fig. 8 shows the effect of aeration on EC of the three different soaking methods. An EC in

water is caused by soluble ions. The EC of soaking water ranges from $1-6 \mathrm{mS} / \mathrm{cm}$ during the soaking time (Thushyanthy et al. 2016). The EC value of all three experimental

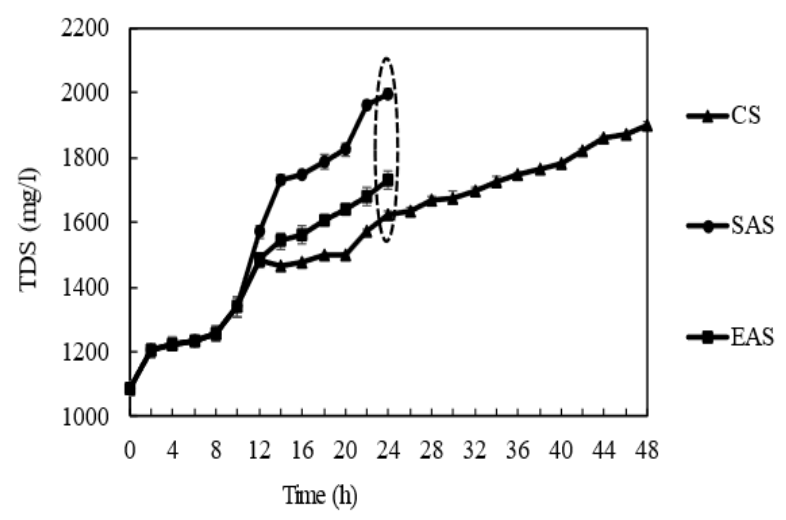

Figure 7: Effect of aeration on TDS of three different soaking methods 
processes increased with the soaking period, but the increase was not gradual. EC of all three different soaking methods gradually increased up to 10 hours of soaking. However, EC changes are very different after 12 hours of soaking in SAS and EAS compared to CS due to the influence of aeration on solid dynamics. It was mixing the soluble ions in the soaking water.

The EC values in $\mu \mathrm{S} / \mathrm{cm}$ for CS, SAS and EAS were $2995 \pm 21.21,2940 \pm 56.56$ and $2790 \pm 42.42$ respectively after 12 hours of soaking. However, EC of the CS water is gradual because of the reduction in the concentration gradient of the soluble ions in the soaking water. After 12 hours, a notable rise was observed in SAS and EAS. The values of EC were $3680 \pm 56.56 \mu \mathrm{S} / \mathrm{cm}$ and $3165 \pm 21.21 \mu \mathrm{S} / \mathrm{cm}$ for after 14 hours of soaking of SAS and EAS respectively. Therefore, the circulation of soaking water increased the ability of soluble ions to be leached from paddy grain. This situation increases the soluble solid dynamics (Kannan 2015).

The EC value was $4005 \pm 7.07 \mu \mathrm{S} / \mathrm{cm}$ after 48 hours for CS. During the period from 12 hours of soaking to 24 hours of soaking, EAS and SAS showed an increasing trend in EC compared to CS. The highest EC value observed for the SAS method was due to high solute concentration due to the leaching of soluble solids.

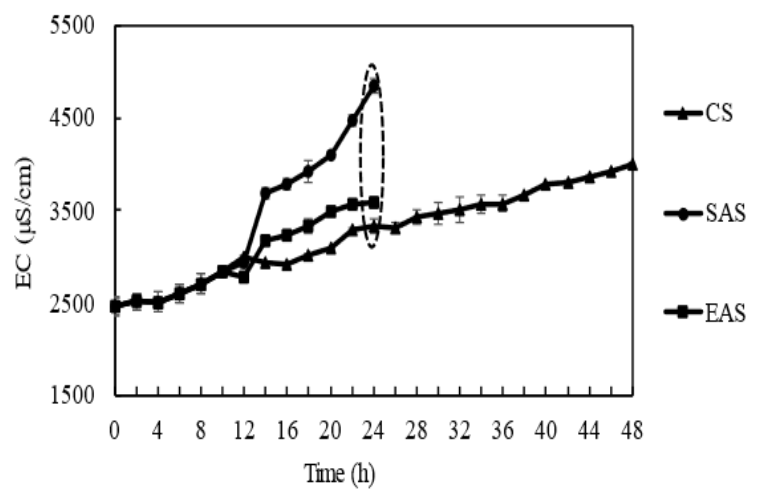

Figure 8: Effect of aeration on EC of three different soaking methods
This highest suction force in submerged aeration resulted in higher leaching rates. Furthermore, the degree of suction force is low for exposed aeration compared to submerged aeration system. Therefore, the EC of the submerged aeration system is high compared to exposed aeration system. A similar pattern has been observed for TDS concentration in three different soaking systems of this experiment. It has been reported that the TDS could be estimated from electrical conductivity (EC). The linear relationship between TDS and EC can be stated as TDS $(\mathrm{mg} / \mathrm{l})=\mathrm{k}_{\mathrm{e}} \times \mathrm{EC}(\mu \mathrm{S} / \mathrm{cm})$. $\left(\mathrm{k}_{\mathrm{e}}\right.$ is a constant of proportionality) (Taylor et al. 2018). Therefore, the observation made in this study matches with reported findings.

\section{pH}

Fig. 9 shows the effect of aeration on the $\mathrm{pH}$ of the three different soaking methods. It is obvious from Fig. 9 that the $\mathrm{pH}$ value gradually decreased during the first 6 hours of soaking for all three soaking methods due to the activation of microbial dynamics between soaking water and paddy grains. After that, during 6 to 8 hours of soaking, an astonishing reduction in $\mathrm{pH}$ was observed in the soaking water due to the proliferation of microbial colonies, resulting in the formation of phenolic compounds in the soaking water (Kannan 2015; Senanayake et al. 2001). However, during 8 to 12 hours of soaking, again gradual decrease was observed due to the microbial activity. The $\mathrm{pH}$ values for $\mathrm{CS}$, SAS and EAS were $6.51 \pm 0.06,6.39 \pm 0.02$ and $6.32 \pm 0.01$ respectively after 12 hours of soaking.

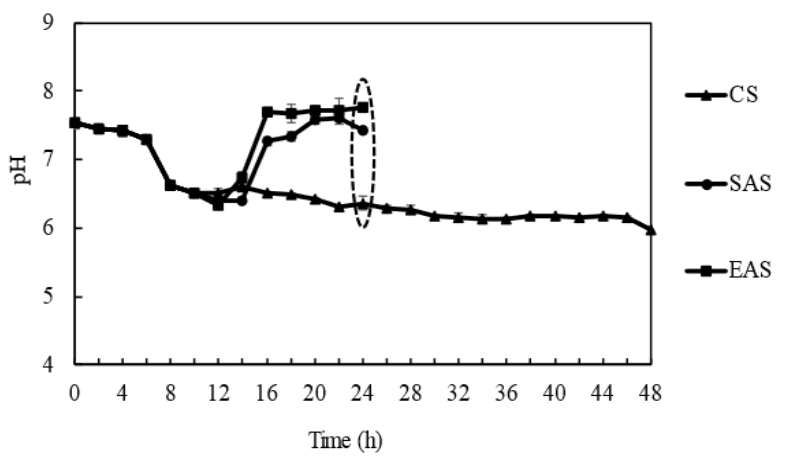

Figure 9: Effect of aeration on $\mathrm{pH}$ of three different soaking methods 
However, $\mathrm{pH}$ changes are very different after 12 hours for SAS and EAS due to recirculation and aeration of the water. Both aerated soaking systems were stopped after 24 hours of soaking as they reached a moisture content of $30 \%(\mathrm{wb})$. The $\mathrm{pH}$ value of $5.97 \pm 0.05$ was obtained in the CS system after 48 hours. During the period from 12 hours to 24 hours of soaking, EAS and SAS showed an increasing trend in $\mathrm{pH}$ compared to CS. SAS, EAS and CS systems had $\mathrm{pH}$ values of $7.42 \pm 0.01,7.76 \pm 0.02$ and $6.36 \pm 0.09$ respectively after 24 hours of soaking. The highest $\mathrm{pH}$ value is observed in the EAS system due to high DO concentration than other soaking methods. DO values for CS, SAS and EAS were $2.09 \pm 0.01,2.19 \pm 0.02$ and $3.145 \pm 0.10 \mathrm{mg} / 1$ respectively after 24 hours of soaking. Therefore, aeration increased the $\mathrm{pH}$ value in soaking water (Ramalingam and Raj 1996).

\section{Total Solids (TS)}

Fig. 10 shows the effect of aeration on TS of the different soaking methods. It is obvious that the TS values curiously increased during the first 4 hours of soaking for all three methods due to the higher concentration of solid that existed between grains and soaking water. This concentration gradient induced the movement of solids into soaking water. Moreover, during 4 to 12 hours of soaking, TS values decreased gradually due to the microbial activity (Kannan 2015). The total solid increased in all three different soaking methods with different patterns.

The TS values for CS, SAS and EAS were $1.85 \pm 0.17 \mathrm{~g} / 1,1.86 \pm 0.18 \mathrm{~g} / 1$ and $1.69 \pm 0.01 \mathrm{~g} / 1$ respectively after 12 hours of soaking. However, TS changes were very different after 12 hours of soaking in submerged and EAS due to the recirculation of the water. During 12 to 14 hours of soaking substantial rise was observed in the TS value due to recirculation of the water, resulting in higher leaching of solids from the paddy grains. Moreover, the TS value includes both TDS and TSS (total suspended solid) (APHA 1992).
During the period from 12 hours to 24 hours of soaking in EAS and SAS, an increasing trend in TS was observed, compared to CS. However, this increasing trend was observed in SAS. However, it was not gradual in EAS. SAS and EAS had TS values of $3.08 \pm 0.03 \mathrm{~g} / \mathrm{l}$, $3.06 \pm 0.01 \mathrm{~g} / 1$ and $1.69 \pm 0.07 \mathrm{~g} / 1$ respectively after 24 hours of soaking. The highest TS value was observed in SAS and EAS compared to CS. Moreover, both aerated soaking systems got the almost same value of TS content in soaking water at 24 hours of soaking. These changes are due to differences in the microbial population, which influenced the DO dynamics and TS in soaking water.

\section{The relationship between TDS and DO of three different soaking methods}

The relationship between TDS (mg/l) and DO $(\mathrm{mg} / \mathrm{l})$ of three different soaking methods, CS, SAS and EAS systems are shown in Fig. 11. It is obvious that different soaking systems have different degrees of relationships between TDS and DO. The conventional soaking system exhibited a better indirect relationship between TDS and DO. The TDS concentration in the soaking system was high as DO concentration was considered to be low. This scenario can be explained by considering the microbial population and organic substances degradation pattern with DO concentration in the soaking water. At high DO concentration, the aerobic microbes were active and the chemical degradation rate was also high, resulted in lower TDS concentration.

It is opposite to lower DO concentrations which were related to higher TDS in wastewater (Muigai et al. 2010). However, the

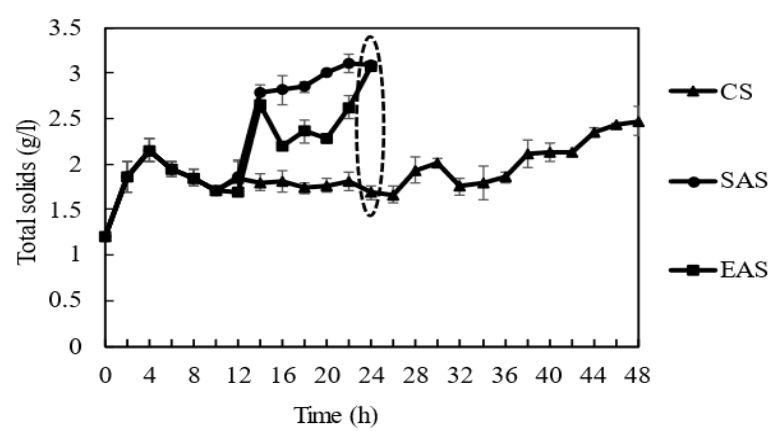

Figure 10: Effect of aeration on TS of three different soaking methods 

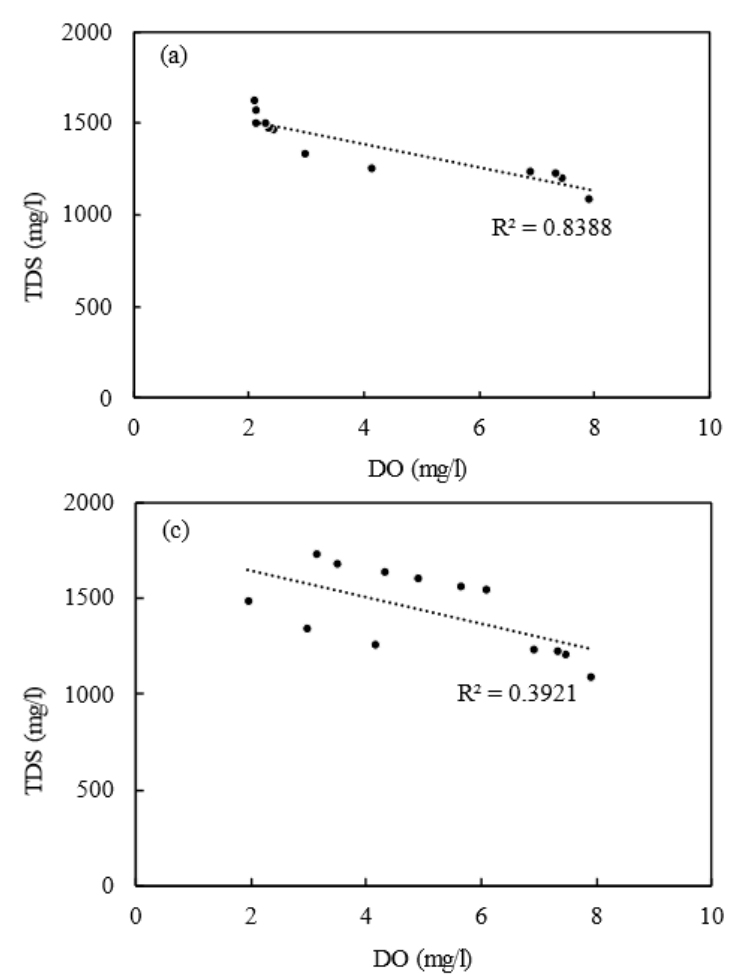

relationship between TDS and DO for SAS and EAS system is not well correlated as of the influence given to DO profile of soaking water by deliberate aeration which made different patterns of soluble solids degradation. The $\mathrm{R}^{2}$ value of SAS and EAS is 0.4861 and 0.3921 respectively, which show a weak relationship between TDS and DO. It has been reported that the TDS concentration of soaking water is influenced by DO concentration during soaking. The same observations were obtained in water eutrophication (Muigai et al. 2010).

\section{The relationship between $\mathrm{pH}$ and DO of different soaking methods}

The relationship between $\mathrm{pH}$ and DO (mg/l) of three different soaking methods, CS, SAS and EAS are shown in Fig. 12. The relationship between $\mathrm{pH}$ and $\mathrm{DO}$ is positively correlated. The CS system exhibited a direct relationship between $\mathrm{pH}$ and $\mathrm{DO}$. The $\mathrm{pH}$ in the soaking system was low as DO concentration was low. This scenario can be explained by considering the microbial population and organic substances degradation pattern with DO concentration in soaking water. At high DO concentration, the

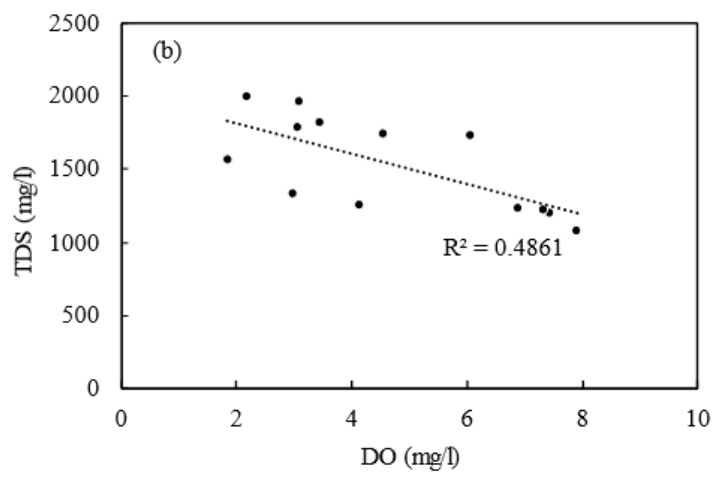

Figure 11: The correlation analysis of TDS and DO of CS (a); SAS (b); EAS (c)

aerobic microbes utilized dissolved oxygen. Therefore, the system is exposed to the anaerobic condition. Due to this anaerobic condition, fermentation of starch occurred, resulting in the formation of acid substances like volatile acids produced by anaerobic microbes in the soaking water environment (Kannan 2015).

Due to this microbial activity, $\mathrm{pH}$ was reduced when DO concentration was reduced. However, the relationship between DO and $\mathrm{pH}$ for SAS and EAS system is not well correlated as of the influence given to DO profile of soaking water by deliberate aeration which made different patterns of the microbial population. The soaking water environment was kept above $1 \mathrm{mg} / \mathrm{l}$ of dissolved oxygen value. The increasing trend in $\mathrm{pH}$ of soaking water with DO has been reported during paddy soaking (Kumari et al. 2014a).

The $\mathrm{R}^{2}$ values of SAS and EAS are 0.0744 and 0.1255 respectively, which show the weak relationship between $\mathrm{pH}$ and DO. It has been reported that the $\mathrm{pH}$ of soaking water was highly influenced by DO concentration during soaking. Researchers reported the $\mathrm{pH}$ 

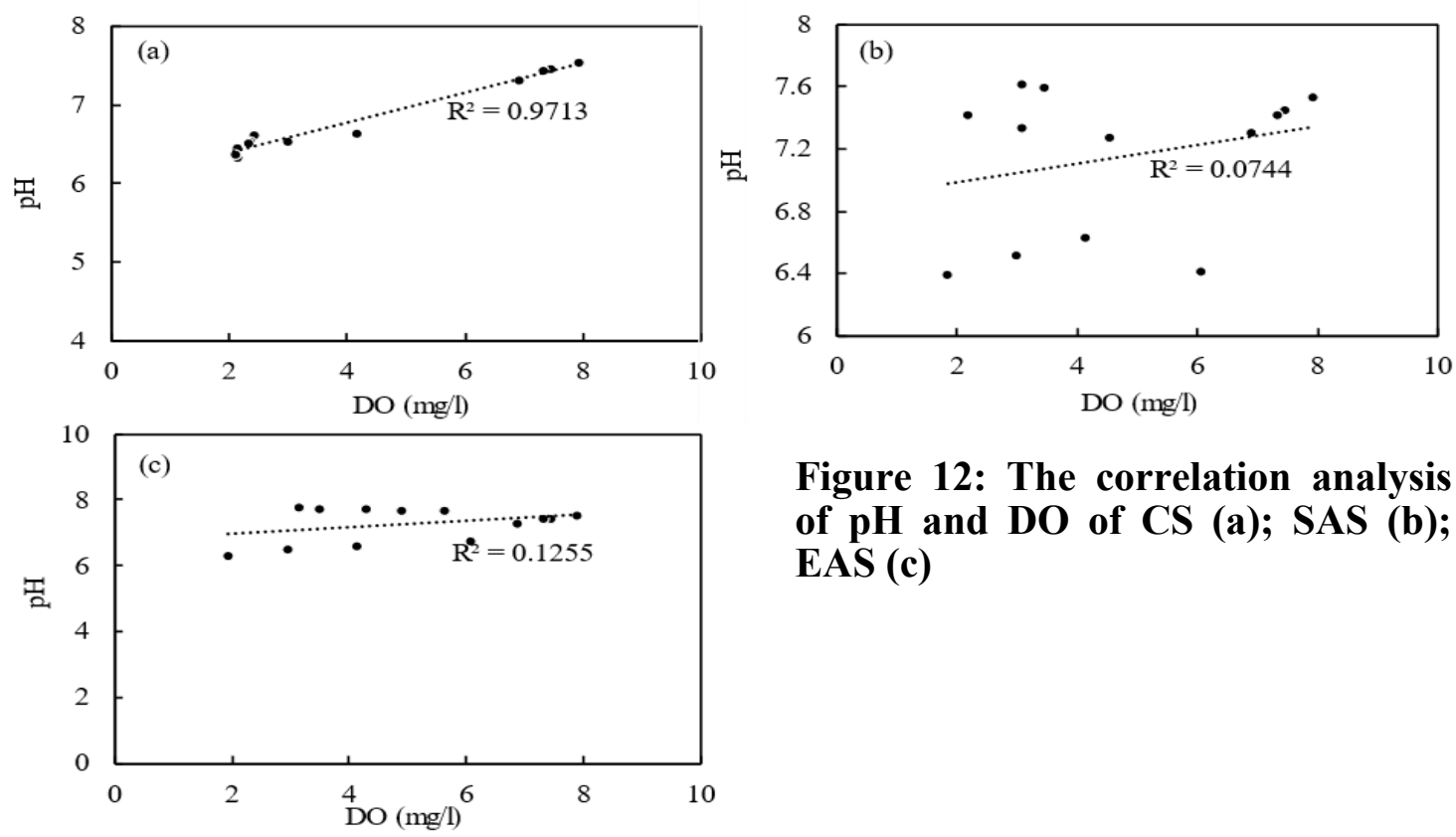

Figure 12: The correlation analysis of pH and DO of CS (a); SAS (b); EAS (c)

of soaking water had been influenced by microbial activities. Moreover, the DO and $\mathrm{pH}$ of soaking water influenced the availability of the organic matter (Kannan 2015; Kumari et al. 2014a; Ramalingam and Raj 1996).

\section{Effect of aeration on milling yield of paddy}

Long paddy grain samples, that were soaked by CS, SAS and EAS methods were steamed and sun-dried. Then, milling recovery, head rice percentage, broken rice percentage, heatdamaged grain percentage, whitebelly percentage and whiteness value of milled rice samples were analysed. The following sections are set to discuss outcomes obtained from milling yield analysis.

\section{Milling recovery}

Fig. 13 shows the milling recovery of three different soaking methods of $\mathrm{Bg} 251$ paddy. There was no remarkable difference among the three different soaking methods in terms of milling recovery. Percentages of milled rice recovery of CS, SAS and EAS were $74 \%$, $72.55 \%$ and $72.9 \%$ respectively after the removal of husk and bran. The amount of milled rice recovered during milling is determined by a number of factors, including the type of paddy, the amount of milling needed, the quality of the equipment used, and the operators (Dhankhar 2014).
According to the above statement, the same amount of the same type of paddy was milled. Therefore, no notable changes were observed in milled rice, bran and husk in terms of yield.

\section{Head rice and broken rice percentage}

Fig. 14 shows the head rice percentage of different three soaking methods. There was no remarkable difference observed between CS and SAS in terms of head rice percentage. However, a considerable difference was observed between EAS and SAS in terms of head rice percentage due to paddy grain germination as of the higher DO concentration in the soaking water. Therefore, soaked paddy grains were exposed to the higher oxygen concentration in exposed aeration than the other two methods. It induced metabolic

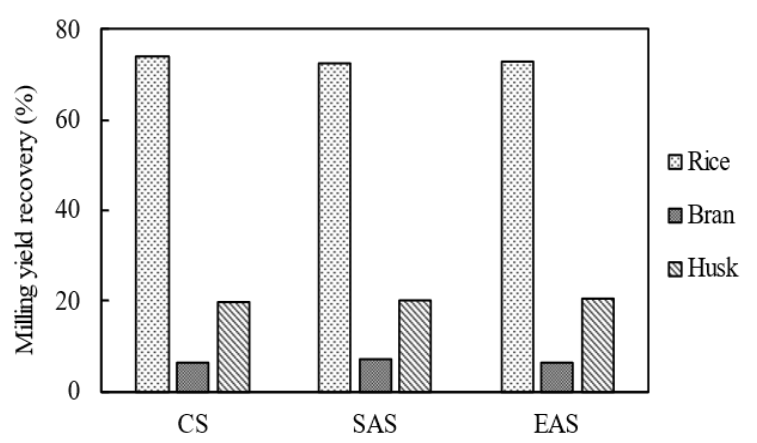

Figure 13: Milling recovery of different soaking methods 
activities of paddy, resulting in germination. Due to this, the head rice percentage of EAS was reported to be low than the other two methods. The values of head rice percentage of CS, SAS and EAS were 79.15 $\pm 1.15 \%$, $79.51 \pm 1.62 \%$ and $60.74 \pm 2.00 \%$ respectively.

Furthermore, the broken rice percentage of EAS increased due to paddy germination. Germination of paddy reduced the milling yield percentage (Han et al., 2016). The values of broken rice percentage of CS, SAS and EAS were $20.84 \pm 1.15 \%, 20.48 \pm 1.16 \%$ and $39.25 \pm 1.99 \%$ respectively. Broken rice

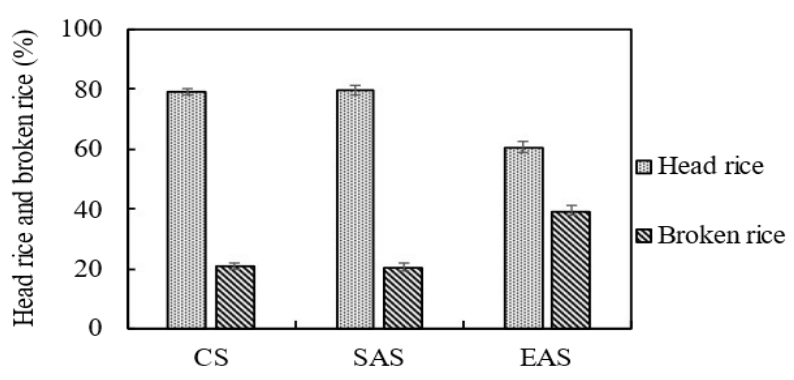

Figure 14: Head rice and broken rice percentage of different soaking methods percentage goes down as head rice percentage increases.

Regression analysis of white bellies, heatdamaged grains and whiteness value of parboiled rice

Fig. 15 (a, b and c) shows the whitebelly, whiteness value and heat damaged-grains of three different soakings of parboiled paddy grains. Fig. 15 (a) indicates the whitebelly percentages of CS, SAS and EAS $1.16 \pm 0.10 \%, \quad 1.32 \pm 0.02 \%$ and $1.33 \pm 0.05 \%$ respectively. Fig. 15 (b) shows the whiteness value percentages of CS, SAS and EAS were $20.16 \pm 0.05,20.76 \pm 0.37$ and $20.83 \pm 0.30$. Fig. 15 (c) displays the heat-damaged grains percentages of CS, SAS and EAS were $0.9 \pm 0.26,1.36 \pm 0.04$ and $1.65 \pm 0.23$. The long time it took to reach the moisture content of $30 \%(\mathrm{wb})$ in the CS resulted in the uniform moisture migration to the centre of the paddy grains, which in turn turned into a lower whitebelly percentage. However, the quick moisture absorption in SAS and EAS systems left the centre of the paddy grain not hydrated with water, which produced a higher whitebelly percentage (Buggenhout et al.,
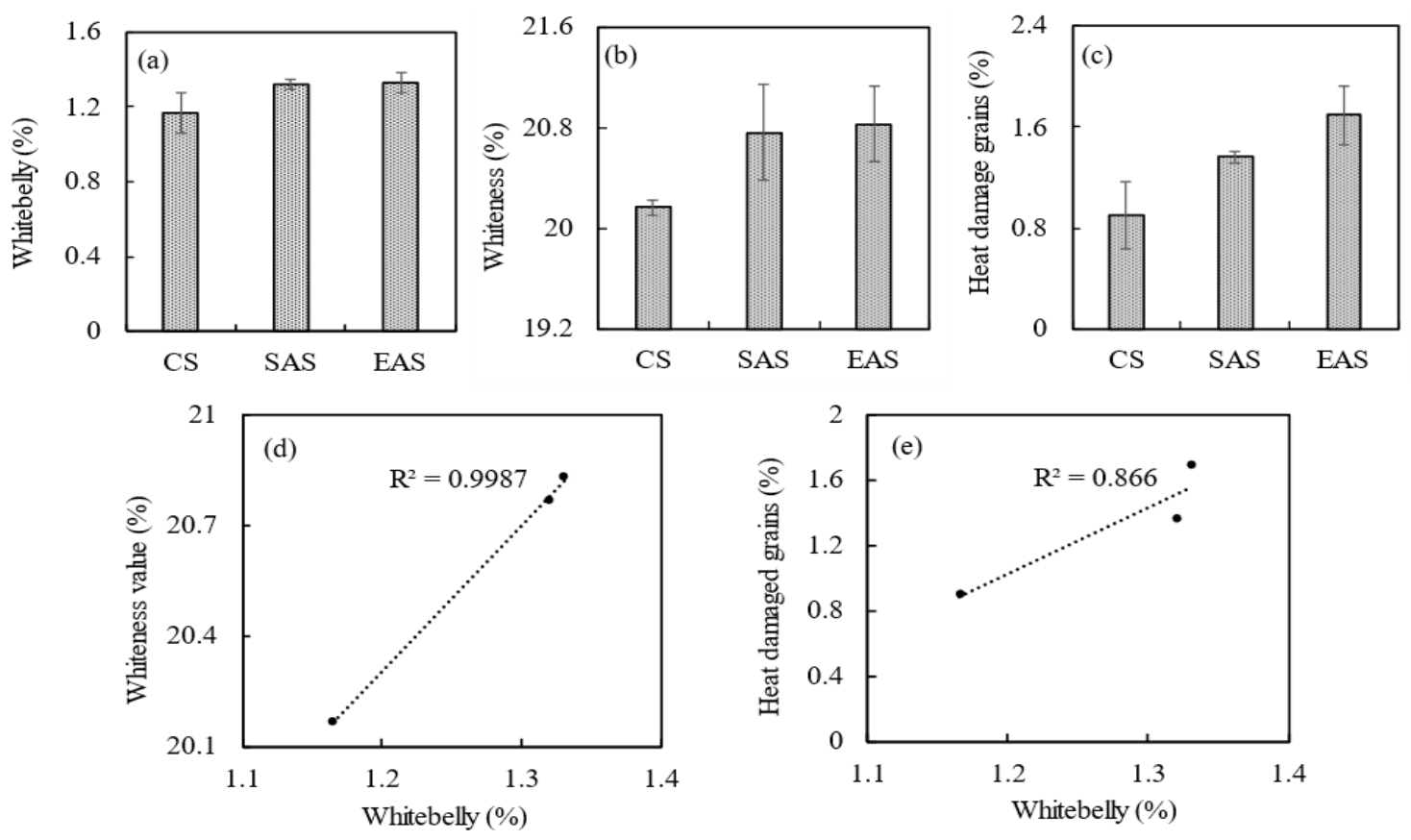

Figure 15: The scenario of whitebelly (a); whiteness value (b); and heatdamaged grains (c); and regression analysis of whiteness value and whitebelly (d); and heat-damaged grains and whitebelly (e) of three different soaking methods. 
2014). Moreover, whitebellies are formed due to poor migration of moisture into paddy grains. Furthermore, whitebellies also influence the whiteness value of grains. This statement was supported by regression analysis of whitebelly and whiteness value as shown in the Fig. 15 (d). It is obvious from the Fig. 15 (d) that the whitebelly percentage and whiteness values are positively correlated $\left(\mathrm{R}^{2}-0.9987\right)$.

In a research study, it has been reported that the whitebelly grains increased the value of whiteness percentage (Nagato et al. 1974). As the whitebellies are sensitive to heat damage, the percentage of heat-damaged grain is high in SAS and EAS systems as shown in the Fig. 15 (c). Moreover, a direct relationship was observed between the whitebelly percentage and heat-damaged grain percentage as shown in Fig. 5 (e) with the $\mathrm{R}^{2}$ value of 0.866 . In a research study, it has been reported that the moisture migration into paddy grain during soaking influences whitebelly percentage at the time of milling and the weakness of whitebellies is most likely due to air gaps or voids at the centre of grains (Buggenhout et al. 2014). Therefore, it is important to regulate the moisture migration into paddy grains for having a lower percentage of whitebellies.

\section{CONCLUSION}

This study investigated the effect of aerated soaking on the paddy parboiling process with an intention of proposing an effective way to reduce the quality and quantity of effluent to avoid unnecessary environmental consequences. Moreover, milling yield analysis was done to check the effect of aeration during the soaking process especially on the head rice yield. The effect of aerated soaking on the hydration rate of paddy is highly remarkable compared to CS. The moisture percentage of $30 \%$ (wb) was obtained by 24 hours of soaking in both SAS and EAS systems compared to CS. It therefore expressively reduced the number of water changes. The SAS and EAS systems were able to maintain positive DO in the soaking water. The DO profile in the EAS system was greater than the SAS system as of higher diffusion rates.

The higher DO maintain in the EAS system reduced head rice yield due to the breakage of germinated paddy grains during milling. The effect of SAS on the milling yield is unimportant. However, $1.32 \%$ of whitebelly was observed. It can further be improved by the changing of aeration cycles. This SAS system did not show considerable germination of grain and did not alter milling yield and head rice percentage compared to CS. Hence, the system of SAS is considered as a reliable option for soaking paddy during parboiling in an eco-friendly with a momentous reduction in effluent strength in terms of BOD.

\section{ACKNOWLEDGEMENT}

The authors would like to acknowledge the resources and financial support provided by the Department of Agricultural Engineering, Faculty of Agriculture, University of Jaffna to complete this study successfully.

\section{AUTHOR CONTRIBUTION}

$\mathrm{NC}$ carried out the experiment, interpreted the data and developed the draft manuscript. NK developed the research concept, involved in critical discussion and interpretation of data, revised the manuscript and supervised the entire project (NC-Neshankine Chandraruban; NK-Dr. Nadarajah Kannan).

\section{REFERENCES}

AOAC 2000 Analytical Methods

APHA 1992 Standard methods for the examination of water and wastewater. 18th ed. American Public Health Association, Washington, DC

Bhattacharya KR, Sowbhagya CM, Swamy YMI 1972 Some physical properties of paddy and rice and their interrelations. Journal of the Science of Food and Agriculture. 23:171-186. https:// doi.org/10.1002/jsfa.2740230204

Buggenhout J, Brijs K, Van Oevelen J, Delcour JA 2014 Milling breakage susceptibility and mechanical properties of parboiled brown rice kernels. LWT - Food Science and 
Technology 59:369-375. https:// doi.org/10.1016/j.lwt.2014.05.001

Chemetova C 2013 Influence of abiotic stress factors on VOCs emission from Portuguese rice paddy fields: relation with increased climate change. https:// doi.org/10.13140/2.1.2325.9844

Dhankhar P 2014 Rice Milling, International organization of Scientific Research

Han A, Jinn JR, Mauromoustakos A, Wang, YJ 2016 Effect of parboiling on milling, physicochemical, and textural properties of medium- and long-grain germinated brown rice. Cereal Chemistry 93: 47-52. https:// doi.org/10.1094/CCHEM-01-15-0013$\mathrm{R}$

Hunt M 2019 Impact of Parboiling Processing Conditions on Rice Characteristics. Journal of Chemical Information and Modeling. 53:1689-1699.

Igathinathane C, Chattopadhyay PK, Pordesimo LO 2005 Combination soaking procedure for rough rice parboiling. Transactions of the American Society of Agricultural Engineers. 48:665-671. https:// doi.org/10.13031/2013.18296

Imoudu PB, Olufayo AA 1999 The effect of sun-drying on milling yield and quality of rice. Bioresour. Technol. 74, 267-269.

IRRI 2010 Seed quality-IRRI Rice Knowledge Bank [WWW Document]. URL http:// www.knowledgebank.irri.org/step-bystep-production/pre-planting/seedquality (accessed 5.8.21)

Itoh K, Kawamura S, Ikeuchi YO 1985 Processing and milling of parboiled rice. Journal of the Faculty of Agriculture, Hokkaido University. 62 (3): 312-324

Kale SJ, Jha SK, Nath P 2017 Soaking effects on physical characteristics of basmati (Pusa Basmati 1121) rice. Agricultural Engineering International: CIGR Journal. 19:114-123

Kannan N 2015 Investigation of a ResourceEfficient Technique for Paddy Parboiling Industry 33:51-62. https:// doi.org/10.5829/

idosi.wasj.2015.33.01.14563

Kannan N, Dharmasena DAN, and Mannapperuma J 2012 Effect of Aeration on Dissolved Oxygen Profile and Hydration During Cold Soaking in Paddy Parboiling Process. International Conference on Sustainable Built Environment, Candy, Sri Lanka, 14-16 December, 2012. http://www.civil.mrt.ac.lk/ conference/ ICSBE2012/SBE-12115.pdf

Kubo M, Purevdorj M 2004 The Future of Rice Production and Consumption. Journal of Food Distribution Research. 35:128-142

Kumari GGKPS, Udyani HGA, Dharmasena DAN, Mannapperuma JD 2014a Effect of water recirculation, aeration and $\mathrm{pH}$ of soaking water on moisture absorption rate of paddy during soaking [WWW Document].

URLhttps://manualzz.com/ download $/ 47341498$

3.18.21).

Kumari GGKPS, Udyani HGA, Dharmasena DAN, Mannapperuma JD 2014b Moisture absorption rate of paddy and effluent quality in parboiling of paddy under aerated and un-aerated water recirculation, in: Proceedings of the Peradeniya Univ. International Research Sessions, (iPURSE) Sri Lanka. 18:213p

Mamadou FJW, John M, Koichi F, Paul VM, Espérance Z, Bléoussi TMR 2011 Effect of improved parboiling methods on the physical and cooked grain characteristics of rice varieties in Benin. International Food Research Journal. 18:715-721

Muigai P, Shiundu P, Mwaura F, Kamau G 2010 Correlation between dissolved oxygen and total dissolved solids and their role in the eutrophication of Nairobi Dam. Kenya. International Journal of BiochemiPhysics 18:37 (5):15-17

Nadvornikova M, Banout J, Herak D, Verner V 2018 Evaluation of physical properties of rice used in traditional 
Kyrgyz Cuisine. Food Science \& Nutrition. 6:1778-1787. https:// doi.org/10.1002/fsn3.746

Nagato K, Suzuki S, Sado T 1974 On the Whiteness of Rice Grains. Japanese Journal of Crop Science. 43:550-556. https://doi.org/10.1626/jcs.43.550

Ouyang CF, Juan CT 1995 A study of a modified process for the intermittent cycle extended aeration system. Water Science Technology. 31:173-180. https://doi.org/10.1016/0273-1223(95) 00419-N

Panchan K and Naivikul O 2009 Effect of pre germination and parboiling on brown rice properties Asian Journal of Food and Agro-Industry 5:256-263.

Pokhrel A, Dhakal A, Sharma S and Poudel A 2020 Evaluation of Physicochemical and Cooking Characteristics of Rice (Oryza sativa L.) Landraces of Lamjung and Tanahun Districts, Nepal. International Journal of Food Science 2020:1-11. https:// doi.org/10.1155/2020/1589150

Pradhan A and Sahu SK 2004 Process details and effluent characteristics of a rice mill in the Sambalpur District of Orissa. Journal of Industrial Pollution Control 20:111-124.

Ramalingam N and Raj SA 1996 Studies on the soak water characteristics in various paddy parboiling methods. Bioresource Technology 55:259-261. https://doi.org/10.1016/0960-8524(96) 00001-6

Rathnayake H, Kulatunga A, Dissanayake T, Mawatha J and Lanka S 2010 Enhancing sustainability of local rice mills by cleaner production and industrial ecological principles, in: International Conference on Sustainable Built Environment (ICSBE-2010). pp. 13-14.

Ravi P and Venkatachalam T 2014 Important engineering properties of paddy [WWW Document]. URL https:// www.researchgate.net/ publication/304351942_Important engineering properties of paddy (accessed 4.20.21).
Sartaj IZ and Suraweera SAER 2005 Comparison of different parboiling methods on the quality characteristics of rice. Annals of the Sri Lanka Department of Agriculture 7: 245-252.

Sayanthan S and Thusyanthy Y 2018 Rice Parboiling and Effluent Treatment Models: A Review. IntInternational journal of research studies in agricultural sciences 4:17-23. https:// dx.doi.org/10.20431/24546224.0405004

Senanayake S, Basnayake B and Mowjood M 2001 Aerated Soaking of Paddy for Rice Parboiling and its Effect on Effluent Kinetics. Proceedings \& abstracts of the Annual Research Sessions 2001,Unviersity of Peradeniya, Peradeniya, Sri Lanka,pp.12

Taylor M, Elliott HA and Navitsky LO 2018 Relationship between total dissolved solids and electrical conductivity in Marcellus hydraulic fracturing fluids. Water Science \& Technology 77:1998 -2004. https://doi.org/10.2166/ wst.2018.092

Thakur AK and Gupta AK 2006 Water absorption characteristics of paddy, brown rice and husk during soaking. JJournal of Food Engineering 75:252$257 . \quad \mathrm{https}: / /$ doi.org/10.1016/ j.jfoodeng.2005.04.014

Thupeeban S and Kannan N 2017 Investigation of Physicochemical Changes of Rice and Soaking Water during Cooking Department of Agricultural Engineering University of Jaffna , Sri Lanka 17, 422-426. https:// doi.org/10.5829/ idosi.aejaes.2017.422.426

Thushyanthy M, Balakumar S and Prabhaharan M 2016 Management of paddy soaking water: As a source for enriched compost making.2nd international conference on structural engineering and construction management 2012.

Varnamkhasti MG, Mobli H, Jafari A, Keyhani AR, Soltanabadi MH, Rafiee S and Kheiralipour K 2008 Some physical properties of rough rice 
international conference on structural engineering and construction management 2012.

Varnamkhasti MG, Mobli H, Jafari A, Keyhani AR, Soltanabadi MH, Rafiee S and Kheiralipour K 2008 Some physical properties of rough rice (Oryza Sativa L.) grain. Journal of Cereal Science 47:496-501. https:// doi.org/10.1016/j.jcs.2007.05.014

Wimberly JE 1983 Technical handbook for the paddy rice post-harvest industry in developed countries, international rice research institute, Manila, pp 330-340.

Xi M, Lin Z, Zhang X, Liu Z, Li G, Wang Q, Wang S and Ding Y 2014 Endosperm structure of white-belly and whitecore rice grains shown by scanning electron microscopy. Plant Production Science 17:285-290. https:// doi.org/10.1626/PPS.17.285 